(1)

George Fox

UNIVERSITY
Digital Commons @ George Fox University

2018

CEO Characteristics and Corporate Philanthropy in Times of Organizational Crisis

Wonsuk Cha

Dongjun Rew

Follow this and additional works at: https://digitalcommons.georgefox.edu/gfsb

Part of the Business Commons 


\title{
CEO characteristics and corporate philanthropy in times of organizational crisis
}

\author{
Wonsuk Cha \\ Governors State University, USA \\ Dongjun Rew \\ University of Texas Rio Grande Valley, USA
}

\begin{abstract}
While corporate philanthropy has been considered a firm's reputation management activity, less research has focused on the relationship between CEOs as the ultimate decision maker and corporate philanthropy, particularly when organizational crises occur. To fill this research gap, this study examines certain CEO characteristics (such as founder status and CEO network) and two causes of philanthropy (such as business-related philanthropy and cause-related philanthropy). This study suggests that there will be a positive relationship between these characteristics of CEOs and causes of corporate philanthropy, and organizational crises will moderate that relationship. This study contributes to a new conceptual framework to explore the relationship between CEO characteristics and different corporate philanthropic causes following organizational crises. This study discusses the scholarly suggestions of our conceptual framework and concludes with implications for future research.
\end{abstract}

\section{Keywords}

corporate philanthropy, corporate social responsibility, CEO characteristics, organizational crisis

\section{Introduction}

The importance of corporate philanthropy continues to be a topic of intense debate among both scholars and practitioners. On the one hand, corporate philanthropy can enhance a firm's reputation, thereby improving performance among key stakeholders (Fombrun and Shanley, 1990; Godfrey, 2005; Porter and Kramer, 2002; Wang and Qian, 2011; Williams and Barrett, 2000). On the other hand, there is a pessimistic perspective about a firm's philanthropic engagement by arguing that a firm exists primarily to generate economic returns, not to solve societal problems (e.g. corporate charitable giving to poverty and hunger) (Devinney, 2009; Friedman, 1970; Vaaland et al., 2008). Despite this discrepancy, firms engage in corporate philanthropy because it helps to fulfill humanitarian needs and firms also believe in the notion, "doing well by doing good." Therefore, it can be suggested that corporate philanthropy should be an important business goal of the firm.

In addition to benevolent characteristics, firms tend to use corporate philanthropy strategically to enhance business benefits from their philanthropic contributions. Strategic philanthropy can play a key role in developing value-creating relationships with primary stakeholders, enhancing a firm's image, and developing the support of local government (Brammer and Millington, 2005; Lii and Lee, 2012; Saiia et al., 2003). Stakeholder theory provides a theoretical foundation by indicating that socially favorable activities are a requirement for maintaining business legitimacy and are positively associated with a firm's performance over the long term (Freeman, 1984). Importantly, firms strategically use corporate philanthropy to maintain a good reputation and repair a bad reputation caused by corporate crises. It is suggested that firms use their philanthropic engagement specifically when executives feel organizational pressure ${ }^{1}$ caused by corporate crises. Past research suggests that corporate philanthropy can mitigate the risks of reputational losses and secure critical resources from stakeholders, hence, providing insurance-like protection to stakeholders (Godfrey, 2005). From this phenomenon, it is suggested that corporate philanthropy can be

\section{Corresponding author:}

Wonsuk Cha, Governors State University, College of Business, I University Parkway, University Park, IL 60484-0975, USA.

Email: wcha@govst.edu 
used a strategic tool for enhancing a firm's reputation which is positively related to business legitimacy.

Despite the extensive discussions of a firm's perspective on philanthropy (Godfrey, 2005; Wang and Qian, 2011), how corporate executives utilize their firm's philanthropy has not received much attention. Among corporate executives (senior executives and board members), CEOs have prominent roles in deciding a firm's philanthropic engagement. They tend to think strategically about philanthropy to enhance brand name recognition, employee productivity, and even to overcome regulatory obstacles (Seifert et al., 2003; Smith, 1994). Despite an important role of CEOs on corporate philanthropy, the relationship between CEO characteristics and corporate philanthropy seems underdeveloped (Galaskiewicz, 1997; Marquis and Lee, 2013). It has been suggested that corporate philanthropy becomes a strategic tool that CEOs implement for instilling customer loyalty, enhancing employee morale, and building community relations (Porter and Kramer, 2002). Importantly, CEOs are the primary decision maker of the organization so that an examination of CEOs' attitudes and values toward philanthropy can provide needed insight into the social responsibility actions in general and philanthropic function in particular (Dennis et al., 2009; Wood, 1991). From this phenomenon, it is suggested that more scholarly effort should be given the relationship between CEO characteristics and corporate philanthropy.

The purpose of this study is to examine the relationship between CEO characteristics and corporate philanthropy, particularly when organizational crises occur. Specifically, this study focuses on the relationship between certain CEO characteristics (such as founder status and CEO network) and causes of philanthropy (such as business-related philanthropy (BRP) and non-BRP). Past research suggests that CEO network is strategically valuable to firms (Geletkanycz and Boyd, 2011; Mizruchi, 1996). CEOs have two types of network (such as intensive network within their industry and extensive network outside their industry) to gain better information from external environment (Ozman, 2006; Rowley and Baum, 2008). In addition, past research suggests that a firm's charitable contributions have specific objectives (e.g. either business gains or social benefits) (Porter and Kramer, 2002). Throughout a theoretical comparison of CEO characteristics and causes of philanthropy, this study suggests that there will be a certain relationship between CEO characteristics (such as founder status and CEO network) and causes of philanthropy and the relationship will change, particularly when organizational crises occur.

This study attempts to answer two research questions. First, what is the relationship between CEO characteristics (such as founder status and CEO network) and causes of philanthropy? Second, what is the role of organizational crises on that relationship? This study contributes to a new conceptual foundation to explore the relationship between CEO characteristics and different corporate philanthropic causes following organizational crises. In addition, this study will extend the current understanding of how certain CEO characteristics can be related to a firm's philanthropic strategy. Through a thorough literature review, seven propositions are presented. This study then continues with discussion and implications and concludes with limitations and directions for future research.

\section{Theory and hypothesis development}

\section{Corporate philanthropy and CSR}

Corporate social responsibility (CSR) refers to "economically sustainable business activities that go beyond legal requirements to protect the well-being of employees, communities, and the environment" (Heslin and Ochoa, 2008: 126). Corporate philanthropy represents "a discretionary manifestation of CSR that differs in kind from the obligation with economic, legal, or moral dimensions of CSR" (Carroll, 1991: 41). For example, corporate philanthropy includes gifts, such as time and monetary contributions given by corporations to social and charitable causes, including those associated with education, culture, the arts, minorities, health care, and disaster relief (Choi and Wang, 2007; Godfrey, 2005). Importantly, both are not mutually exclusive and the similarity between two is taking care of others. The difference is that the former seems to broadly focus on other issues that affect the environment, consumers, and human right for the good of the world, but the latter seems to narrowly focus on helping others by charitable giving and time.

\section{Corporate philanthropy and reputation management}

The increasing importance of corporate philanthropy and a firm's reputation is well-documented in the CSR literature (Brammer and Millington, 2006; Godfrey, 2005; Williams and Barrett, 2000). Corporate reputation refers to a cognitive representation of a company's actions and results that crystallizes the firm's ability to deliver valued outcomes, such as financial, social, and environmental impacts, to its stakeholders over time (Barnett et al., 2006; Fombrun et al., 2000). Importantly, both corporate philanthropy and corporate reputation have a mutual relationship to support society and act as a bridge to receive a favorable association with stakeholders and the public. For example, past research found that corporate philanthropy positively influences stakeholders and reputation (Brammer and Millington, 2006; Fombrun and Shanley, 1990). In addition, corporate philanthropy might offset the negative impact of illegal activities on reputation to some extent and help reduce bad reputation (Muller and Kräuss, 2011; Williams and Barret, 2000). Table 1 shows a summary of studies on corporate philanthropy and reputation.

It has been suggested that corporate philanthropy helps recover reputation induced by corporate wrongdoing, illegal activities, and misconduct so that it helps mitigate a tense of organizational crises (Williams and Barrett, 2000). An organizational crisis refers to "a lowprobability, high-impact even that threatens the viability of the organization and is characterized by ambiguity of cause, effect, and means of resolution, as well as by a belief that decisions must be made swiftly" (Pearson and Clair, 
Table I. A summary of studies on corporate philanthropy and reputation.

\begin{tabular}{|c|c|c|c|}
\hline Study & Orientation & Sample & Key findings/arguments \\
\hline $\begin{array}{l}\text { Bae and } \\
\text { Cameron } \\
(2006)\end{array}$ & Empirical & $\begin{array}{l}\text { Seventy-two undergraduate students } \\
\text { (between-subject experiment } \\
\text { design) }\end{array}$ & $\begin{array}{l}\text { Prior corporate reputation, one responsibility of a public relation } \\
\text { department affects public perceptions toward corporate } \\
\text { philanthropic messages and ultimately affects public attitudes } \\
\text { toward the company }\end{array}$ \\
\hline $\begin{array}{l}\text { Brammer and } \\
\text { Pavelin } \\
\quad(2005)\end{array}$ & Conceptual & & $\begin{array}{l}\text { Social investments, such as corporate philanthropy, are a form of } \\
\text { insurance in that they protect the value of a company's } \\
\text { reputation asset from the harm that accompanies events that } \\
\text { are perceived by stakeholders as indicators of social } \\
\text { irresponsibility }\end{array}$ \\
\hline $\begin{array}{l}\text { Brammer and } \\
\text { Milington } \\
(2005)\end{array}$ & Empirical & $\begin{array}{l}\text { Ten largest firms in } 24 \text { industrial } \\
\text { sectors in the United Kingdom }\end{array}$ & $\begin{array}{l}\text { Companies which make higher levels of philanthropic } \\
\text { expenditures have better reputations and this effect varies } \\
\text { significantly across industries }\end{array}$ \\
\hline Dean (2003) & Empirical & $\begin{array}{l}\text { University students (laboratory } \\
\text { experimental design) }\end{array}$ & $\begin{array}{l}\text { The average firm enhanced its image by pursuing an unconditional } \\
\text { donation, but a conditional donation did not damage the firm's } \\
\text { image }\end{array}$ \\
\hline $\begin{array}{l}\text { Godfrey } \\
\quad(2005)\end{array}$ & Conceptual & & $\begin{array}{l}\text { A reputation for corporate philanthropy can help protect a firm's } \\
\text { relationships with its stakeholders and thus reduce the firm's } \\
\text { risk of losing critical resources }\end{array}$ \\
\hline Meijer (2009) & Empirical & Five charitable organizations & $\begin{array}{l}\text { The reputation of a charity is an important factor in attracting } \\
\text { donors }\end{array}$ \\
\hline $\begin{array}{l}\text { Muller and } \\
\text { Kräuss } \\
(2011)\end{array}$ & Empirical & $\begin{array}{l}\text { Four hundred and forty-two fortune } \\
500 \text { firms }\end{array}$ & $\begin{array}{l}\text { Reputation for social irresponsibility was associated with both the } \\
\text { greatest drop in stock prices and the greatest likelihood of } \\
\text { making a subsequent charitable donation in response to the } \\
\text { disaster }\end{array}$ \\
\hline $\begin{array}{l}\text { Lii and Lee } \\
\qquad(2012)\end{array}$ & Empirical & $\begin{array}{l}\text { Four hundred and ninety-two } \\
\text { undergraduate students }\end{array}$ & $\begin{array}{l}\text { CSR initiatives, such as sponsorship, cause-related marketing, and } \\
\text { philanthropy, have a significant effect on customer-company } \\
\text { identification and brand attitude }\end{array}$ \\
\hline $\begin{array}{l}\text { Porter and } \\
\text { Kramer } \\
(2002)\end{array}$ & Conceptual & & $\begin{array}{l}\text { The company that initiates corporate philanthropy in a particular } \\
\text { area will often get disproportionate benefits because of the } \\
\text { superior reputation and relationships it builds. However, if a } \\
\text { company's philanthropy only involved its own interests, after } \\
\text { all, it would not qualify as a charitable deduction, and it might } \\
\text { well threaten the company's reputation }\end{array}$ \\
\hline $\begin{array}{l}\text { Porter and } \\
\text { Kramer } \\
(2006)\end{array}$ & Conceptual & & $\begin{array}{l}\text { The philanthropy will have a real impact on the company's long- } \\
\text { term success, and the company's giving will deliver far greater } \\
\text { benefits to society, to the people it is trying to help }\end{array}$ \\
\hline $\begin{array}{l}\text { Reinstein and } \\
\text { Riener } \\
(2012)\end{array}$ & Empirical & $\begin{array}{l}\text { Eighty males and } 112 \text { females } \\
\text { (laboratory experiments) }\end{array}$ & $\begin{array}{l}\text { Leaders are influential only when their identities are revealed } \\
\text { along with their donations, and female leaders are more } \\
\text { influential than males }\end{array}$ \\
\hline $\begin{array}{l}\text { Williams and } \\
\text { Barrett } \\
(2000)\end{array}$ & Empirical & $\begin{array}{l}\text { I84 Fortune } 500 \text { firms from 1991 } \\
\text { through } 1994\end{array}$ & $\begin{array}{l}\text { Firms that violate EPA regulations should, to some extent, } \\
\text { experience a decline in their reputations, while firms that } \\
\text { contribute to charitable causes should see their reputations } \\
\text { enhanced }\end{array}$ \\
\hline $\begin{array}{l}\text { Wang and } \\
\text { Qian (20II) }\end{array}$ & Empirical & $\begin{array}{l}\text { Chinese firms listed on stock } \\
\text { exchanges from } 2001 \text { to } 2006\end{array}$ & $\begin{array}{l}\text { The positive philanthropy performance relationship is stronger } \\
\text { for firms with greater public visibility and for those with better } \\
\text { past performance, as philanthropy by these firms gains more } \\
\text { positive stakeholder responses }\end{array}$ \\
\hline
\end{tabular}

CSR: corporate social responsibility.

1998: 60). In general, an organizational crisis is a significant event that brings damage or harm to stakeholders, the public, and particularly organization itself. The examples of organizational crises mainly include product recalls and lawsuits because both are the most sensitive and high impact that can threaten organizations. Table 2 below shows the cases of high profile organizational crises.

\section{Overview of causes of corporate philanthropy}

Porter and Kramer (2002) suggest that firms engage in corporate philanthropy with different purposes in order to build reputation. Broadly, firms have three different purposes (such as communal obligation, goodwill building, and strategic giving) of philanthropy for the following:

First, communal obligation refers to support of civic, welfare, and educational organizations, motivated by the company's desire to be a good citizen. Second, goodwill building refers to contributions to support causes favored by employees, customers, or community leaders, often necessitated by the desire to improve the company's relationships. Third, strategic giving refers to philanthropy focused on enhancing competitive context. (Porter and Kramer, 2002: 13) 
Table 2. Cases of high profile organizational crises.

\begin{tabular}{ll}
\hline Cases & Description \\
\hline $\begin{array}{l}\text { Dukes versus } \\
\text { Walmart stores }\end{array}$ & $\begin{array}{c}\text { Sexual discrimination class-action lawsuit } \\
\text { for denied promotion filed in } 2000 \text { by } \\
\text { Betty Dukes and other former female } \\
\text { employees } \\
\text { BP oil spill }\end{array}$ \\
& $\begin{array}{l}\text { BP Oil spill in the Gulf of Mexico in 2010- } \\
\text { largest accidental oil spill in the } \\
\text { Petroleum industry. In November 20I2, } \\
\text { BP settled criminal charges with } \\
\text { Department of Justice for around } \\
\text { US\$4 billion } \\
\text { Merck's Vioxx (Painkiller drug) product } \\
\text { liability lawsuit filed in 2006 by a John } \\
\text { McDarby resulted in US\$4.5 million } \\
\text { punitive fines after the jury finds that } \\
\text { company intentionally misled FDA }\end{array}$ \\
Johnson \& Johnson & $\begin{array}{l}\text { Johnson \& Johnson's Tylenol-related death } \\
\text { in Chicago due to product tampering } \\
\text { (cyanide poisoning) }\end{array}$ \\
\hline
\end{tabular}

Source: The Wall Street Journal and http://www.businessinsurance.com.

Some firms engage in corporate philanthropy with the first purpose which may not be related to their businesses. Other firms engage in corporate philanthropy with the second and third purpose, both of which are more likely related to their businesses so that they attempt to connect their charitable contributions to their business activities. With the three different purposes of corporate philanthropy, this study develops two causes of philanthropy: BRP and causerelated philanthropy (CRP).

BRP, commonly known as strategic philanthropy, refers to

an activity of a firm that involves choosing how it will voluntarily allocate resources to charitable or social service activities in order to reach marketing and other business-related objectives for which they are no clear social expectations as to how the firm should perform. (Ricks, 2002: 117)

It would be designed to contribute to direct monetary gain, just as are other functions of the firm (Sánchez, 2000). For example, corporations undertake philanthropy as long as direct economic benefits can be gained by doing so (Bock, 1984). Therefore, BRP explicitly links its philanthropic strategy with a corporate objective. CRP, called business-unrelated philanthropy, refers to one where the activities have nothing to do with advancing the mission (Porter and Kramer, 2002). Firms engage in nonbusiness charitable activities without concern for reward (Lantos, 2002). In general, the altruistic type of corporate philanthropy can be considered CRP (Sharfman, 1994; Useem, 1984). For instance, charitable contributions are not related to the business objectives such that they only can generate social benefits (Porter and Kramer, 2002). Table 3 shows the examples of BRP and CRP.

In conclusion, it can be suggested that corporate philanthropy has a mutual relationship with a firm's reputation so it helps reduce a tense of organizational crises. In addition, it can be suggested that a firm's philanthropic engagement consists of two causes, such as BRP and CRP. Recent research suggests that organizations are social entities where decisions are made by actors with various interests (Gautier and Pache, 2015). Accordingly, it is important to examine the relationship between organizational leaders and corporate philanthropy.

In the following section, this study will look at the role of executives on corporate philanthropy. Interestingly, CEOs view corporate philanthropy as a legitimate perquisite of leadership (Barnard, 1996). Past research argues that a firm's strategic decisions of philanthropic engagement mainly depend on CEOs (Porter and Kramer, 2002). To reflect an important role of CEO on corporate philanthropy, this study will specifically explore the link between CEO characteristics and corporate philanthropy.

\section{The role of organizational leaders and corporate philanthropy}

Corporate philanthropy is part of strategies that organizational leaders implement (Porter and Kramer, 2002) and they have an important role in terms of a firm's philanthropic engagement. The predominant discussion of organizational leaders and corporate philanthropy has been on board of directors (BODs) (Bear et al., 2010; Kabongo et al., 2013; Williams, 2003), top managers (Choi and Wang, 2007; Rahbek Pedersen and Neergaard, 2009) and CEOs (Chin et al., 2013; Dennis et al., 2009; Jiraporn and Chintrakarn, 2013; Li et al., 2015).

Several scholars have had an interest in the relationship between BODs and corporate philanthropy (Cha and Abebe, 2016; Kabongo et al., 2013; Williams, 2003). They found that firms having more inside directors, a higher proportion of female directors, and diverse BODs do engage in corporate philanthropy more. It has been suggested that "the values of top management have an imprint on the firm, influencing decision-making processes, stakeholder salience, and corporate social performance" (Rahbek Pedersen and Neergaard, 2009: 1263). In addition, Choi and Wang (2007: 345) suggested that "top managers with benevolence and integrity values are more likely to spread their intrinsic concern for others into the wider society in the form of corporate philanthropy."

Other scholars have focused on CEO characteristics (e.g. CEO's integrity and altruism, and CEO tenure) to explain a firm's philanthropic decisions (e.g. Dennis et al., 2009; Godfrey, 2005). For example, CEO personal values and priorities often shape the giving practices in many public companies such that CEOs' influence over the specific corporate giving is very much alive and well (Chin et al., 2013; Choi and Wang, 2007). Importantly, CEOs view corporate philanthropy as a legitimate perquisite of leadership (Barnard, 1996). This is because having business legitimacy is important part of corporate strategies so CEOs value it the most. From this, it is suggested that CEO characteristics and personal network might explain how firms gain business legitimacy through corporate philanthropy. It might be anticipated that institutional pressures 
Table 3. Overview of BRP and CRP.

\begin{tabular}{|c|c|c|}
\hline & BRP & CRP \\
\hline Definition & $\begin{array}{l}\text { An effective corporate giving that can reach marketing and } \\
\text { business-related objectives and that benefit serve business } \\
\text { interests. }\end{array}$ & $\begin{array}{l}\text { Advancing the mission and charitable contributions } \\
\text { unrelated to the business and generating only social } \\
\text { benefits }\end{array}$ \\
\hline $\begin{array}{l}\text { Concepts } \\
\text { Purpose }\end{array}$ & $\begin{array}{l}\text { Something to do with business and shareholders focused. } \\
\text { It is where a given objective is closely related to a } \\
\text { corporation's core activities. } \\
\text { It is only where corporate expenditure produces } \\
\text { simultaneous social and economic gains so that corporate } \\
\text { philanthropy and shareholder interests converge. }\end{array}$ & $\begin{array}{l}\text { Nothing to do with business and stakeholders focused } \\
\text { The desired benefit is enhanced good will, not improvement } \\
\text { in a company's ability to compete. } \\
\text { It is generating goodwill and positive publicity and boosting } \\
\text { employee morale. }\end{array}$ \\
\hline Cases & $\begin{array}{l}\text { Since 2010, Walmart has provided cash and food to fight } \\
\text { hunger together at the local, state, and national level } \\
\text { (http://www.foundation.walmart.com). } \\
\text { SAP (multinational company) has donated free software to } \\
\text { local organizations in South Africa and it meets firms' } \\
\text { long-term strategy as tech hubs from India to Africa, } \\
\text { "Value creation" (http://www.tripundit.com). }\end{array}$ & $\begin{array}{l}\text { The Coca-Cola company donated US } \$ 6 \text { million aimed at } \\
\text { improving the lives of an estimated } 250,000 \text { women and } \\
\text { girls on the African continent in } 201 \text { I (http://www.csrwire. } \\
\text { com). } \\
\text { BP (oil giant) donated US\$I million to American Red Cross } \\
\text { and The Salvation Army in } 2012 \text { (http://www. } \\
\text { huffingtonpost.com). }\end{array}$ \\
\hline
\end{tabular}

Note: Cases were obtained from each firm's website and The Wall Street Journal. BRP: business-related philanthropy; CRP: cause-related philanthropy.

from personal network with which CEOs are connected can encourage a firm's philanthropic engagement. Table 4 below indicates a summary of research on organizational leadership and corporate philanthropy.

\section{CEO characteristics and corporate philanthropy}

Since CEO unethical behaviors made Enron field for bankruptcy in 2001, CEO ethical values and attitudes have been recognized as an important aspect when thinking about CSR activities. Therefore, it is important to examine how CEOs ethical behavior is transferred to stakeholder's concern, in turn influencing a firm's philanthropy. In addition, past research suggests that CEOs are willing to use their personal network as the best available information which helps them to decide a better strategic plan (Burt, 2000). Therefore, it might be anticipated that CEO network can be considered a useful strategic means when making a firm's philanthropic engagement.

CEOs are interested in a firm's philanthropic activities due to the social responses to the communities in which the firm operates (Berman et al., 1999; Wood and Jones, 1995) and an activity that stimulates goodwill toward companies within those communities (Brammer and Millington, 2005). Importantly, there is empirical evidence that CEOs' integrity and altruism are positively associated with CSR (Adams and Hardwirk, 1998; Waldman et al., 2006). Transformational leadership (Bass, 1997) can support a theoretical foundation of this relationship. For example, charismatic leaders maintain deeply held personal values (such as integrity, justice, and ethics), reflecting a helping concern for others and providing motivational effects with others (Kanungo, 2001; Waldman et al., 2006). More specifically, several scholars suggest that founder CEOs often exhibit deep personal attachment and passion for their firms so they have a high social capital, reputation, and goodwill among external stakeholders of the firm (Bamford et al., 2006; Fischer and Pollock, 2004; Ling et al., 2007; Nelson, 2003).
As part of important CEO characteristics, CEO network linked with external stakeholders would appear to be a powerful means to develop a competitive advantage for their firms (Bamford et al., 2006). CEO network represents the system of relationships that the CEO has with organizational members and other actors outside of their organization (Geletkanycz and Hambrick, 1997). Because the existence of external board members can offer the link to other organizations, such as channels for communication and support from external organization (Hillman and Dalziel, 2003; Salancik and Pfeffer, 1978), CEOs tend to serve outside boards to reduce information asymmetry and to maximize business benefits. For example, CEOs serving on outside boards may offer valuable strategic advice to cope with a variety of problems that their firms may encounter during growth (Carpenter and Westphal, 2001; Rindova, 1999). Therefore, it can be suggested that CEOs serving on outside boards help gain a peer relationship with other CEOs so that CEOs can get exposed to other management styles which can affect overall business plan.

Importantly, CEO network can reflect a channel to existing social causes and needs which subsequently link to corporate philanthropy. Past research suggests that the network of contacts among organizations within a field can drive organizations toward isomorphism and that individuals in structurally similar positions are expected to express similar perceptions and attitudes (Galaskiewicz and Burt, 1991; Zucker, 1987). In detail, a professional community (e.g. corporate boards) can have a social structure of multiple positions, each with its own, internally producing beliefs and attitudes about professional works. Extending this logic, it can be suggested that CEO network is more likely related to corporate philanthropy because CEOs serving on outside boards may tend to have a similar norm and interest as well as causes with serving firms in terms of a firm's philanthropic decisions.

In conclusion, it can be suggested that CEOs engage in corporate philanthropy to meet social responses to the communities and goodwill toward their firms. Notably, 
Table 4. A summary of research on organizational leadership and corporate philanthropy.

\begin{tabular}{|c|c|c|c|c|}
\hline Studies & Theory & Focus & Sample & Key findings/arguments \\
\hline $\begin{array}{l}\text { Brown et al. } \\
\quad(2006)\end{array}$ & Agency & BODs & $\begin{array}{l}\text { Two hundred and seven fortune } \\
500 \text { in } 1998\end{array}$ & $\begin{array}{l}\text { Firms with larger BODs are associated with } \\
\text { significantly more cash giving and with the } \\
\text { establishment of corporate foundations }\end{array}$ \\
\hline $\begin{array}{l}\text { Campbell } \\
\text { et al. } \\
\text { (1999) }\end{array}$ & Stakeholder & Managers & $\begin{array}{l}\text { One hundred and thirty-nine } \\
\text { food distributors and } \\
\text { producers }\end{array}$ & $\begin{array}{l}\text { The human element of personal attitudes may } \\
\text { interact and play a very important role in a firm's } \\
\text { decision to become involved with philanthropic } \\
\text { activities }\end{array}$ \\
\hline $\begin{array}{l}\text { Chin et al. } \\
(2013)\end{array}$ & $\begin{array}{l}\text { Upper } \\
\text { echelons }\end{array}$ & CEOs & $\begin{array}{l}\text { Two hundred and forty-nine } \\
\text { CEOs of S\&P I } 500 \text { firms } \\
\text { between } 2004 \text { and } 2006\end{array}$ & $\begin{array}{l}\text { Compared with conservative CEOs, liberal CEOs } \\
\text { exhibit greater advances in CSR initiatives. The } \\
\text { influence of CEOs' political liberalism on CSR } \\
\text { initiatives (civic and philanthropic activities) is } \\
\text { amplified when they have more power }\end{array}$ \\
\hline $\begin{array}{l}\text { Choi and } \\
\text { Wang } \\
(2007)\end{array}$ & Stakeholder & $\begin{array}{l}\text { Top } \\
\text { management }\end{array}$ & Conceptual & $\begin{array}{l}\text { Top managers with benevolence and integrity } \\
\text { values are more likely to spread their intrinsic } \\
\text { concern for others into the wider society in the } \\
\text { form of corporate philanthropy }\end{array}$ \\
\hline $\begin{array}{l}\text { Dennis et al. } \\
\text { (2009) }\end{array}$ & $\begin{array}{l}\text { Theory of } \\
\text { planned } \\
\text { behavior }\end{array}$ & CEOs & $\begin{array}{l}\text { Four hundred and ninety-nine } \\
\text { CEOs from publicly held US } \\
\text { firms in } 2004\end{array}$ & $\begin{array}{l}\text { The most important determinant of a firm's } \\
\text { philanthropy is the degree to which the CEO } \\
\text { identifies himself or herself as a philanthropist }\end{array}$ \\
\hline $\begin{array}{l}\text { Galaskiewicz } \\
\text { (1997) }\end{array}$ & Institutional & Managers & The city of Minneapolis & $\begin{array}{l}\text { Managers making decisions about corporate } \\
\text { philanthropy are subject to institutional pressure } \\
\text { to give in a certain way-both personal } \\
\text { interaction and corporate reputation }\end{array}$ \\
\hline $\begin{array}{l}\text { Ibrahim and } \\
\text { Angelidis } \\
\text { (1995) }\end{array}$ & $\begin{array}{l}\text { Upper } \\
\text { echelons }\end{array}$ & BODs & $\begin{array}{l}\text { Three hundred and ninety-eight } \\
\text { corporate directors }\end{array}$ & $\begin{array}{l}\text { Compared to their male counterparts, female } \\
\text { directors exhibit a stronger orientation toward } \\
\text { the discretionary component (philanthropy) of } \\
\text { CSR. Male board members, on the other hand, } \\
\text { are more concerned with the economic } \\
\text { component of CSR }\end{array}$ \\
\hline $\begin{array}{l}\text { Kabongo } \\
\text { et al. } \\
\text { (2013) }\end{array}$ & $\begin{array}{l}\text { Resource } \\
\text { dependence }\end{array}$ & CEOs/BODs & $\begin{array}{l}\text { Four thousand, four hundred } \\
\text { and thirty-eight US firms } \\
\text { between |99| to } 2009\end{array}$ & $\begin{array}{l}\text { Firms with diverse BODs and female CEOs have a } \\
\text { positive effect on the level of corporate } \\
\text { philanthropy }\end{array}$ \\
\hline $\begin{array}{l}\text { Marquis and } \\
\text { Lee }(2013)\end{array}$ & $\begin{array}{l}\text { Upper } \\
\text { echelons }\end{array}$ & BODs & $\begin{array}{l}\text { Fortune } 500 \text { firms during the } \\
\text { period 1996-2006 }\end{array}$ & $\begin{array}{l}\text { Characteristics of senior management and } \\
\text { directors affect corporate philanthropic } \\
\text { contributions. For example, the shorter CEO } \\
\text { tenure, the higher female directors, and the } \\
\text { more central director interlock network will be } \\
\text { higher corporate philanthropic contributions }\end{array}$ \\
\hline $\begin{array}{l}\text { Werbel and } \\
\text { Carter } \\
\text { (2002) }\end{array}$ & & CEOs & $\begin{array}{l}\text { All US corporate foundations } \\
\text { with assets greater than two } \\
\text { million dollars }\end{array}$ & $\begin{array}{l}\text { CEO's extensive network, as measured by } \\
\text { membership in different nonprofit organizations, } \\
\text { is associated with foundation charitable giving }\end{array}$ \\
\hline $\begin{array}{r}\text { Williams } \\
(2003)\end{array}$ & Stakeholder & BODs & $\begin{array}{l}\text { One hundred and righty-five } \\
\text { firms from Fortune } 500 \text { for } \\
\text { the } 1991-1994 \text { time period }\end{array}$ & $\begin{array}{l}\text { Firms having a higher proportion of women serving } \\
\text { on boards do engage in charitable giving to a } \\
\text { greater extent than firms having a lower } \\
\text { proportion of women serving on their boards }\end{array}$ \\
\hline
\end{tabular}

BOD: board of director; CSR: corporate social responsibility.

corporate philanthropy is highly related to CEOs' moral capital (ethical, integrity, and justice) which is a fundamental element for receiving a favorable response from publics. Specifically, charismatic leadership that founder CEOs have highly links with their ethical values, reflecting a helping concern for stakeholders. In addition, CEO network may offer the same norm and causes of philanthropy as serving firms do. Therefore, it can be suggested that certain $\mathrm{CEO}$ characteristics are closely related to a firm's philanthropic causes. ${ }^{2}$ In the following section, this study will explore the relationship between CEO characteristics (such as founder status and CEO network) and causes of philanthropy, particularly when organizational crises occur. Figure 1 below shows a theoretical model of this study.

\section{CEO founder status and CRP}

The literature reviewed suggests that firms can have different causes of philanthropy, such as BRP and CRP. Specifically, this study suggests that founder CEOs will engage in CRP more than non-founder CEOs for the following reasons. First, founder CEOs have more commitment to the firm than non-founder CEOs. For example, founder CEOs contribute almost everything they have for their firm so that such contributions will lead the founders to be more strongly identified with and committed to the firm than 


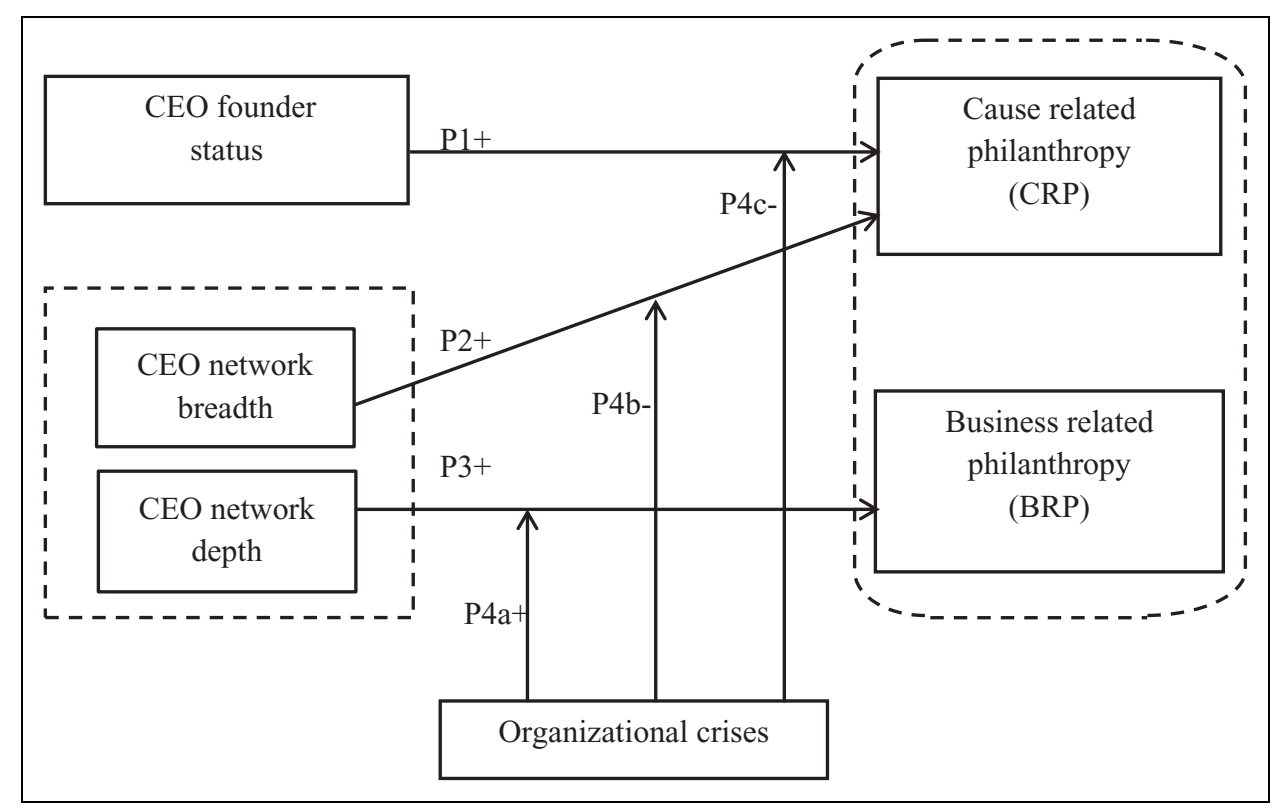

Figure I. A proposed theoretical model.

non-founder CEOs (Arthurs and Busenitz, 2003). The logic is that the more commitment CEOs have in their firms, the more they want their firms to meet publics' expectation which is highly correlated with corporate philanthropy. On the other hand, non-founder CEOs are more likely to be obsessed by managerial hubris so they may neglect to pay attention to the continuing commitment. Since CRP is more likely to generate goodwill and positive publicity, focusing on stakeholders, founder CEOs' continuing commitment will be more likely to match with CRP.

Second, founder CEOs' interest is directly connected with their firm. Therefore, their intrinsic motivation is better motivated to affect stakeholders in a long-term perspective, including the continuing commitment by business to behave ethically. For example, past research suggests that founder CEOs with moral values tend to give more effort to social activities, in fact positively influencing a long-term value of their firms (Hernandez, 2008). In addition, it has been suggested that founder CEOs often have a high social capital, reputation, and goodwill among external stakeholders of the firm (Bamford et al., 2006; Fischer and Pollock, 2004; Nelson, 2003). CRP is a firm's charitable activities which are less likely to be associated with advancing core business activities (Porter and Kramer, 2002). Therefore, CRP is more likely to offer social benefits and represents the company's desire to be a good citizen in a long-term perspective. Accordingly, this study states the following proposition:

Proposition 1: CEO founder status will be positively related to CRP such that founder-led firms will invest more in CRP than non-founder-led firms.

\section{CEO network breadth and CRP}

Past research found that the network among external organizations can function as valuable strategic advice, information, and support to firms (Carpenter and Westphal, 2001; Hillman and Dalziel, 2003; Rindova, 1999; Salancik and Pfeffer, 1978). Importantly, the CEO as the ultimate decision maker for the firm tends to maintain their network either extensively or intensively. For example, some CEOs might have intensive network (depth) within their industry, and others have extensive network (breadth) outside their industry (Ozman, 2006; Rowley and Baum, 2008). In addition, past research suggests that corporate philanthropy includes two causes, such as business related and nonbusiness related (Porter and Kramer, 2002; Ricks, 2002). From this, it might be anticipated that there is a certain relationship between two types of CEO network and two causes of philanthropy. Specifically, this study suggests that CEO network breadth will be positively related to CRP for the following reasons.

CEOs' interpretation of the environment can be a result of their personal contacts as well as relationships with their social network. For example, it has been found that CEOs with broad network ties are exposed to broad information environment (Galaskiewicz, 1997; Saiia et al., 2003), which helps enable them to generate goodwill and social benefits beyond business interests. In addition, past research suggests that CEOs' extra industry network (e.g. network outside their industry, "breadth") is positively associated with the adoption of nonconforming business strategy (Geletkanycz and Hambrick, 1997), which includes charitable contributions unrelated to their businesses. Furthermore, it has been suggested that CEOs with network breadth can strive to satisfy diverse stakeholders' interests, providing social benefits in the long-term perspective (Saiia et al., 2003). CEO network breadth can provide firms with social benefits and focus on stakeholders' interests (Porter and Kramer, 2002), and CRP is not closely related to business objectives and provides only social benefits in the long term. Accordingly, this study states the following proposition: 
Proposition 2: CEO network breadth will be positively related to CRP.

\section{CEO network depth and BRP}

This study suggests that CEO network depth will be positively related to BRP for the following reasons. First, an intensive network (depth) ${ }^{3}$ can enable CEOs to access rich and timely information about the firm's internal and external environment related to their businesses. Therefore, CEO network depth can offer a deeper understanding of the firm's exploitative and exploratory options (Mehra et al., 2006), which include other firms' philanthropic decisions. Second, past research suggests that CEOs with network depth are exposed to restricted task environments which make CEOs focus on corporation core activities rather than general environments (Abebe et al., 2010; Williamson and Cable, 2003). For example, CEOs' intraindustry network (e.g. network within their industry) tends to focus on the immediate task environments (e.g. customers, suppliers, and competitor sectors) rather than general environments (e.g. social causes and needs as well as humanitarian needs). Extending this logic, it might be anticipated that CEO network depth is highly related to a firm's philanthropic activities which are related to economic gains and shareholders' interests. Third, CEO network depth can influence resource allocation in philanthropy as CEOs seek to achieve isomorphism in their businesses. For instance, CEOs serving outside boards within their industry could only focus on philanthropic expenditures that are closely related to same objectives and benefits as serving firms do.

CEO network depth can offer business benefits based on task environments, and BRP is closely related to shareholder values which are simultaneous social and economic gains under corporation's core objectives. Accordingly, this study states the following proposition:

Proposition 3: CEO network depth will be positively related to BRP.

\section{Organizational crises and CEO network}

Past research suggests that corporate philanthropy has been strategically used to restore reputation induced by organizational crises (Williams and Barrett, 2000; Ricks, 2005). In times of crisis, CEOs might need to manage crises by adjusting a firm's strategic decisions, including philanthropic contributions. This study suggests that the relationship between CEO network and causes of philanthropy will change when CEOs feel organizational pressure caused by unexpected organizational crises for the following reasons.

Threat rigidity theory indicates that individuals experiencing crises tend to have a limitation of the information that can or will be received; as a result, crises lead them to focus on primitive forms of reaction (Staw et al., 1981). Therefore, during organizational crises with which decisions must be coped quickly, CEOs of successful firms restrict information search and attention to the task environments (such as customers, suppliers, and competitor sectors). Importantly, it might be anticipated that information-related crisis management (e.g. how other firms deal with similar cases) can be obtained through CEO network depth within their industry. CEOs might become conservative in their resource allocation decisions in philanthropy when organizational crises occur. Extending this logic, this study suggests that the relationship between CEO network depth and BRP will increase in times of organizational crises. This is because CEOs will put more effort on how corporate expenditures (e.g. philanthropic donations) would meet and/or maximize business interests rather than public concern. Accordingly, this study states the following proposition:

Proposition 4a: Organizational crises will positively moderate the relationship between CEO network depth and BRP such that the level of BRP will be higher after crises.

CEOs might reduce spending financial resources to nonessential causes when organizational crises occur. In a situation where CEOs feel organizational pressure caused by external organizational crises, they tend to emphasize their key shareholders' concern in specific. In doing so, CEOs need to change strategic pattern from general environments (e.g. less likely to do with stakeholders focused) in a longterm perspective to task environments (e.g. something to do with businesses and shareholders focused) in a short-term perspective. In addition, CEO network breadth outside their industry is highly related to social benefits rather than business benefits so that it may not provide firms with the immediate cure to reduce the impact of organizational crises. Therefore, this study states the following proposition:

Proposition 4b: Organizational crises will negatively moderate the relationship between CEO network breadth and CRP such that the level of CRP will be lower after crises.

The same argument can be applied to the relationship between founder status and CRP when organizational crises occur. Past research suggests that founder CEOs tend to have high commitments for their firms, and they tend to be more strongly identified with and committed to their firms than non-founder CEOs (Arthurs and Busenitz, 2003). When organizational crises occur, these characteristics can motivate founder CEOs to quickly respond to crises so that founder CEOs can change a firm's philanthropic causes from CRP to BRP. In addition, to reduce shareholders' tensions to organizational crises, founder CEOs could quickly change social value-led philanthropy to business profit-led philanthropy. Therefore, this study states the following proposition:

Proposition 4c: Organizational crises will negatively moderate the relationship between CEO founder 
status and CRP such that the level of CRP will be lower after crises.

\section{Discussion and implications}

When discussing a firm's decisions about philanthropic contributions, an examination of CEO characteristics has become important in light of moral collapses of senior executives in businesses, including what Enron experienced when it filed for bankruptcy in 2001. To meet the demands of the times, this study has examined the relationship between CEO characteristics and corporate philanthropy, particularly when organizational crises occur. Specifically, this study has focused on two types of CEO characteristics, including founder status and CEO network. In addition, this study has focused on different causes of philanthropy, including CRP and BRP. This study has suggested that there will be a positive relationship between CEO characteristics and causes of philanthropy and that relationship will vary, particularly when organizational crises occur.

This study has contributed to a number of suggestions and theoretical framework to the field of strategic leadership and the CSR literature. First, this study has suggested that founder CEOs with moral values can give more effort to social benefits, in fact affecting causes (e.g. nonbusiness related) of corporate philanthropy. This suggestion is consistent with an argument that corporate philanthropy can be the direct result of top managers' benevolence and integrity values, in fact building trusting relationships with stakeholders (Choi and Wang, 2007). Second, this study has suggested that CEO network as a means of CEO strategic connections among organizations is closely related to different causes (e.g. either business related or nonbusiness related) of philanthropy. Third, this study has suggested that CEOs have become conservative in their resource allocation decisions particularly when they sense organizational crises. To meet the threat, CEOs could focus on business and task environments by engaging more in CRP.

This study has also provided three important implications for the following. First, this study has indicated that causes of philanthropy can be closely linked with CEOs' intrinsic motivation and high commitment to the firm. For example, when firms engage more in non-BRP, stakeholders can recognize to what degree CEOs are willing to put their firm's limited resources to social values. Therefore, it can be argued that CEOs' engagement in different causes of philanthropy, such as socially and morally favorable causes (e.g. CRP) or economically favorable causes (e.g. BRP), would act as an important indicator through which stakeholders can determine to what degree CEOs have commitment to the firm, in fact increasing social recognition for the firm in the long-term value.

Second, this study has indicated that CEOs can share similar perceptions and/or attitudes from their business network which can influence the causes of philanthropy. Past research also suggests that CEOs in structurally similar positions within their business network are expected to express similar norm through institutional isomorphism (DiMaggio and Powell, 1983) and influence a firm's decisions of philanthropic contributions (Galaskiewicz and Burt, 1991). Therefore, it can be argued that CEO network explains why there are certain firms which engage in similar causes of philanthropy.

Third, this study has indicated that CEO network can provide firms with effective crisis management in times of organizational crisis. In other words, CEO network can help firms strategically adjust their resource allocation in charitable contributions through causes of philanthropy. Past research suggests that CEOs strategically use corporate philanthropy (Ricks, 2005) and CEO network can be considered a means of a firm's strategic tool. Accordingly, it can be argued that CEOs apply their network to causes of philanthropy so that their firms can restore reputation induced by organizational crises.

\section{Limitations and future research}

This study has a number of limitations that need to be addressed in further studies. First, it is reasonable to providing empirical evidence on the theoretical framework of this study by measuring four distinguished concepts (such as CEO network breadth, CEO network depth, CRP, and BRP). ${ }^{4}$ This attempt can enhance foundation methodologically on the study's theoretical framework in Figure 1. Second, it is recommended that there is a need to include boundaries beyond organizational crises. For example, managerial misconducts or illegal activities (Haley, 1991) might need to be included. Meanwhile, national crises (such as financial crises and earthquakes) also need to be included. This attempt can offer a holistic perspective of the relationship between crisis management and corporate philanthropy. It might be anticipated that firms engage in causes of philanthropy differently depending on managerial, organizational, and national context of crises.

\section{Conclusion}

This study has suggested that engaging in corporate philanthropy is no longer a discretionary action beyond what is expected by a firm. More importantly, corporate philanthropy acts as a strategic tool which can reduce a pessimistic view of critics, particularly when organizational crises occur. In addition, this study has suggested that determining targets and/or causes of philanthropic activities are closely related to certain CEO characteristics. For example, founder CEOs with moral value and intrinsic motivation to the firm would put more effort into social benefits within a long-term orientation for their firm, and their value and motivation can be fulfilled by engaging in CRP more. Furthermore, this study has suggested that CEO network would act as a meaningful signal through which stakeholders can acknowledge how well CEOs address a firm's philanthropic policy within similar institutions. Overall, this study can provide firms with a strategic leadership guide in engaging in philanthropy but also motivate them 
to engage in philanthropy more although they are in bad mood.

\section{Declaration of Conflicting Interests}

The author(s) declared no potential conflicts of interest with respect to the research, authorship, and/or publication of this article.

\section{Funding}

The author(s) received no financial support for the research, authorship, and/or publication of this article.

\section{Notes}

1. In this article, organizational pressure refers to "the external factors which cause staff anxiety and restlessness" (Yang and Yang, 2014: 14). We believe that CEOs tend to proactively take steps to their organizations to organizational crises by addressing a firm's philanthropic strategy. In detail, when facing organizational pressure caused by unexpected organizational crises, CEOs could reframe a firm's philanthropic strategy so as to recover reputation as well as generate positive organizational change.

2. In this article, it might be better to say that causes of philanthropy rather than philanthropic motivations would be more appropriate since the main point of this article is that certain CEO characteristics are closely related to (determine) different causes of philanthropy and the relationship could change when CEOs feel organizational pressure caused by unexpected organizational crises.

3. CEO network helps facilitate information flow (developing from the CEOs' presence on the other firm's boards) to CEOs so it helps play a considerable role in the decision process. In addition, CEO intensive network (network depth) among managerial elites in similar industry helps CEOs to seek information from sources that are more likely to affirm those beliefs.

4. While this study offered a theoretical foundation on the relationship between certain CEO characteristics and causes of philanthropy under organizational crises, this might be considered as less convincing without having empirical evidence. As future study, one plausible way to measure cause-related philanthropy and business-related philanthropy (BRP) would be to distinguish between cash giving and gifts in-kind giving from the total corporate philanthropic activities. As opposed to cash giving, it might be suggested that gifts in-kind giving may be highly related to firms' strategic purposes and missions so that it may genuinely reflect the level of BRP.

\section{References}

Abebe M, Angriawan A and Tran H (2010) Chief executive external network ties and environmental scanning activities: an empirical examination. Strategic Management Review 4(1): $30-43$.

Adams M and Hardwick P (1998) An analysis of corporate donations: United Kingdom evidence. Journal of Management Studies 35(5): 641-654.

Arthurs JD and Busenitz LW (2003) The boundaries and limitations of agency theory and stewardship theory in the venture capitalist/entrepreneur relationship*. Entrepreneurship Theory and Practice 28(2): 145-162.
Bae J and Cameron GT (2006) Conditioning effect of prior reputation on perception of corporate giving. Public Relations Review 32(2): 144-150.

Bamford CE, Bruton GD and Hinson YL (2006) Founder/chief executive officer exit: a social capital perspective of new ventures. Journal of Small Business Management 44(2): 207-220.

Barnard JW (1996) Corporate philanthropy, executives' pet charities and the agency problem. New York Law School Law Review 41: 1147-1178.

Barnett ML, Jermier JM and Lafferty BA (2006) Corporate reputation: the definitional landscape. Corporate Reputation Review 9(1): 26-38.

Bass BM (1997) Does the transactional-transformational leadership paradigm transcend organizational and national boundaries? American psychologist 52(2): 130.

Bear S, Rahman N and Post C (2010) The impact of board diversity and gender composition on corporate social responsibility and firm reputation. Journal of Business Ethics 97(2): 207-221.

Berman SL, Wicks AC, Kotha S, et al. (1999) Does stakeholder orientation matter? The relationship between stakeholder management models and firm financial performance. Academy of Management Journal 42(5): 488-506.

Bock B (1984) The Impact of the Modern Corporation. New York: Columbia University Press.

Brammer S and Millington A (2005) Corporate reputation and philanthropy: an empirical analysis. Journal of Business Ethics 61(1): 29-44.

Brammer S and Millington A (2006) Firm size, organizational visibility and corporate philanthropy: an empirical analysis. Business Ethics: A European Review 15(1): 6-18.

Brammer S and Pavelin S (2005) Corporate reputation and an insurance motivation for corporate social investment. Journal of Corporate Citizenship 2005(20): 39-51.

Brown WO, Helland E and Smith JK (2006) Corporate philanthropic practices. Journal of corporate finance 12(5): $855-877$.

Burt RS (2000) The network structure of social capital. Research in organizational behavior 22: 345-423.

Campbell L, Gulas CS and Gruca TS (1999) Corporate giving behavior and decision-maker social consciousness. Journal of Business Ethics 19(4): 375-383.

Carpenter MA and Westphal JD (2001) The strategic context of external network ties: examining the impact of director appointments on board involvement in strategic decision making. Academy of Management Journal 44(4): 639-660.

Carroll AB (1991) The pyramid of corporate social responsibility: toward the moral management of organizational stakeholders. Business horizons 34(4): 39-48.

Cha W and Abebe MA (2016) Board of directors and industry determinants of corporate philanthropy. Leadership and Organization Development Journal 37(5): 672-688.

Chin MK, Hambrick DC and Treviño LK (2013) Political ideologies of CEOs: the influence of executives' values on corporate social responsibility. Administrative Science Quarterly 58(2): 197-232.

Choi J and Wang H (2007) The promise of a managerial values approach to corporate philanthropy. Journal of Business Ethics 75(4): 345-359. 
Dean DH (2003) Consumer perception of corporate donations effects of company reputation for social responsibility and type of donation. Journal of Advertising 32(4): 91-102.

Dennis BS, Buchholtz AK and Butts MM (2009) The nature of giving a theory of planned behavior examination of corporate philanthropy. Business \& Society 48(3): 360-384.

Devinney TM (2009) Is the socially responsible corporation a myth? The good, the bad, and the ugly of corporate social responsibility. The Academy of Management Perspectives 23(2): 44-56.

DiMaggio PJ and Powell WW (1983) The iron cage revisited: institutional isomorphism and collective rationality in organizational fields. American sociological review 48(2): 147-160.

Fischer HM and Pollock TG (2004) Effects of social capital and power on surviving transformational change: the case of initial public offerings. Academy of Management Journal 47(4): 463-481.

Freeman RE (1984) Strategic Management: A Strategic Approach. New York: Pitman Publishing.

Friedman M (1970) The social responsibility of business is to increase its profits. New York Times Magazine, September 13, pp. 26-32.

Fombrun C and Shanley M (1990) What's in a name? Reputation building and corporate strategy. Academy of management Journal 33(2): 233-258.

Fombrun CJ, Gardberg NA and Barnett ML (2000) Opportunity platforms and safety nets: corporate citizenship and reputational risk. Business and society review 105(1): 85-106.

Galaskiewicz J (1997) An urban grants economy revisited: Corporate charitable contributions in the twin cities, 1979-81, 1987-89. Administrative Science Quarterly 42(3): 445-471.

Galaskiewicz J and Burt RS (1991) Interorganization contagion in corporate philanthropy. Administrative Science Quarterly 36(1): 88-105.

Gautier A and Pache AC (2015) Research on corporate philanthropy: a review and assessment. Journal of Business Ethics 126(3): 343-369.

Geletkanycz MA and Boyd BK (2011) CEO outside directorships and firm performance: A reconciliation of agency and embeddedness views. Academy of Management Journal 54(2): 335-352.

Geletkanycz MA and Hambrick DC (1997) The external ties of top executives: implications for strategic choice and performance. Administrative Science Quarterly 42(4): 654-681.

Godfrey PC (2005) The relationship between corporate philanthropy and shareholder wealth: a risk management perspective. Academy of Management Review 30(4): 777-798.

Haley UC (1991) Corporate contributions as managerial masques: reframing corporate contributions as strategies to influence society*. Journal of Management Studies 28(5): 485-510.

Hernandez M (2008) Promoting stewardship behavior in organizations: a leadership model. Journal of Business Ethics 80(1): 121-128.

Heslin PA and Ochoa JD (2008) Understanding and developing strategic corporate social responsibility. Organizational Dynamics 37(2): 125-144.

Hillman AJ and Dalziel T (2003) Boards of directors and firm performance: integrating agency and resource dependence perspectives. Academy of Management Review 28(3): 383-396.
Ibrahim NA and Angelidis JP (1995) The corporate social responsiveness orientation of board members: Are there differences between inside and outside directors? Journal of business Ethics 14(5): 405-410.

Jiraporn P and Chintrakarn P (2013) How do powerful CEOs view corporate social responsibility (CSR)? An empirical note. Economics Letters 119(3): 344-347.

Kabongo JD, Chang K and Li Y (2013) The impact of operational diversity on corporate philanthropy: an empirical study of US companies. Journal of Business Ethics 116(1): 49-65.

Kanungo RN (2001) Ethical values of transactional and transformational leaders. Canadian Journal of Administrative Sciences 18(4): 257-65.

Lantos GP (2002) The ethicality of altruistic corporate social responsibility. Journal of Consumer Marketing 19(3): 205-232.

Lii YS and Lee M (2012) Doing right leads to doing well: When the type of CSR and reputation interact to affect consumer evaluations of the firm. Journal of Business Ethics 105(1): 69-81.

Li S, Song X and Wu H (2015) Political connection, ownership structure, and corporate philanthropy in China: a strategicpolitical perspective. Journal of Business Ethics 129(2): 399-411.

Ling Y, Zhao H and Baron RA (2007): Influence of founderCEOs' personal values on firm performance: moderating effects of firm age and size $\dagger$. Journal of Management 33(5): 673-696.

Marquis C and Lee M (2013) Who is governing whom? Executives, governance, and the structure of generosity in large US firms. Strategic Management Journal 34(4): 483-497.

Mehra A, Dixon AL, Brass DJ, et al. (2006). The social network ties of group leaders: implications for group performance and leader reputation. Organization science 17(1): 64-79.

Meijer MM (2009) The effects of charity reputation on charitable giving. Corporate Reputation Review 12(1): 33-42.

Mizruchi MS (1996) What do interlocks do? An analysis, critique, and assessment of research on interlocking directorates. Annual Review of Sociology 22(1): 271-298.

Muller A and Kräussl R (2011) Doing good deeds in times of need: a strategic perspective on corporate disaster donations. Strategic Management Journal 32(9): 911-929.

Nelson T (2003) The persistence of founder influence: management, ownership, and performance effects at initial public offering. Strategic Management Journal 24(8): 707-724.

Ozman M (2006) Knowledge integration and network formation. Technological Forecasting and Social Change 73(9): 1121-1143.

Pearson CM and Clair JA (1998) Reframing crisis management. Academy of Management Review 23(1): 59-76.

Porter ME and Kramer MR (2002) The competitive advantage of corporate philanthropy. Harvard Business Review 80(12): 56-68.

Porter ME and Kramer MR (2006) Corporate philanthropy: taking the high ground. The Accountable Corporation: Foundation Strategy Group 13: 1-12.

Rahbek Pedersen E and Neergaard P (2009) What matters to managers? The whats, whys, and hows of corporate social 
responsibility in a multinational corporation. Management Decision 47(8): 1261-1280.

Reinstein D and Riener G (2012) Reputation and influence in charitable giving: an experiment. Theory and decision 72(2): 221-243.

Ricks Jr JM (2002) The Effects of Strategic Corporate Philanthropy on Consumer Perceptions: An Experimental Assessment. Doctoral dissertation, University of New Orleans, US.

Ricks Jr JM (2005) An assessment of strategic corporate philanthropy on perceptions of brand equity variables. Journal of Consumer Marketing 22(3): 121-134.

Rindova VP (1999) What corporate boards have to do with strategy: a cognitive perspective. Journal of Management Studies 36(7): 953-975.

Rowley TJ and Baum JA (2008) The dynamics of network strategies and positions. Advances in Strategic Management 25: 641-671.

Saiia DH, Carroll AB and Buchholtz AK (2003) Philanthropy as strategy when corporate charity "begins at home". Business and Society 42(2): 169-201.

Salancik GR and Pfeffer J (1978) The External Control of Organizations: A Resource Dependence Perspective. NY: Harper and Row Publishers.

Sánchez CM (2000) Motives for corporate philanthropy in El Salvador: altruism and political legitimacy. Journal of Business Ethics 27(4): 363-375.

Seifert B, Morris SA and Bartkus BR (2003) Comparing big givers and small givers: financial correlates of corporate philanthropy. Journal of business ethics 45(3): 195-211.

Sharfman M (1994) Changing institutional rules the evolution of corporate philanthropy, 1883-1953. Business and Society 33(3): 236-269.

Smith C (1994) The new corporate philanthropy. Harvard Business Review 72(3): 105-114.

Staw BM, Sandelands LE and Dutton JE (1981) Threat-rigidity effects in organizational behavior: a multilevel analysis. Administrative Science Quarterly 26(4): 501-524.
Useem M (1984) The Inner Circle: Large Corporations and the Rise of Business Political Activity in the US and UK. Oxford: Oxford University Press.

Vaaland TI, Heide M and Grønhaug K (2008) Corporate social responsibility: investigating theory and research in the marketing context. European Journal of Marketing 42(9/10): 927-953.

Waldman DA, Siegel DS and Javidan M (2006) Components of CEO transformational leadership and corporate social responsibility*. Journal of Management Studies 43(8): 1703-1725.

Wang H and Qian C (2011) Corporate philanthropy and corporate financial performance: the roles of stakeholder response and political access. Academy of Management Journal 54(6): $1159-1181$

Werbel JD and Carter SM (2002) The CEO's influence on corporate foundation giving. Journal of Business Ethics 40(1): $47-60$.

Williams RJ (2003) Women on corporate boards of directors and their influence on corporate philanthropy. Journal of Business Ethics 42(1): 1-10.

Williams RJ and Barrett JD (2000) Corporate philanthropy, criminal activity, and firm reputation: Is there a link? Journal of Business Ethics 26(4): 341-350.

Williamson IO and Cable DM (2003) Predicting early career research productivity: the case of management faculty. Journal of Organizational Behavior 24(1): 25-44.

Wood DJ (1991) Corporate social performance revisited. Academy of Management Review 16(4): 691-718.

Wood DJ and Jones RE (1995) Stakeholder mismatching: a theoretical problem in empirical research on corporate social performance. International Journal of Organizational Analysis 3(3): 229-267.

Yang D and Yang L (2014) Organizational pressure dimensions measuring of "post-80s" employees and its implications for talent strategy. Open Journal of Social Sciences 2(12): 13-18.

Zucker LG (1987) Institutional theories of organization. Annual Review of Cociology 13(1): 443-464. 